Portland State University

PDXScholar

Economics Faculty Publications and

Presentations

Economics

7-2013

\title{
Economics of REDD+ and Community Forestry
}

Randall Bluffstone

Portland State University

Follow this and additional works at: https://pdxscholar.library.pdx.edu/econ_fac

Part of the Economics Commons, and the Sustainability Commons

Let us know how access to this document benefits you.

Citation Details

Bluffstone, Randy (2013). Economics of REDD+ and Community Forestry, Journal of Forest and Livelihood 11(2): 69-74.

This Article is brought to you for free and open access. It has been accepted for inclusion in Economics Faculty Publications and Presentations by an authorized administrator of PDXScholar. Please contact us if we can make this document more accessible: pdxscholar@pdx.edu. 


\section{Economics of REDD+ and Community Forestry (Perspective)

\author{
Randall Bluffstone* \\ "Department of Economics, Portland State University, USA \\ Corresponding author: bluffsto@pdx.edu
}

\section{INTRODUCTION}

Reducing Emission from Deforestation and Forest Degradation (REDD+) is a payment for ecosystem services (PES) system created under the Framework Convention on Climate Change (FCCC) that tries to reduce deforestation and degradation in countries not subject to requirements under the convention (non-Annex 1 countries) and, therefore, release less and sequester more carbon. Other cobenefits have been added, such as biodiversity protection, poverty reduction and afforestation, which make up the ' + ' in REDD+. The ' + ', therefore, attempts to address potentially negative, unintended effects on non-carbon ecosystem services and take account of effects on those who currently have claims to forests. Many of the forest areas where the ' + ' is most important are community managed. Community forestry is therefore at the heart of REDD+.

Fundamentally, REDD+ is about creating markets for carbon sequestration services where REDD+ buyers are in FCCC Annex 1 countries and sellers remain in non-Annex 1 countries. These markets, which presumably will be linked to other created carbon markets, are believed to be necessary because of the common pool nature of carbon sequestration services. Services from common pool resources are depletable and difficult to defend from intrusion and/or depletion. For example, carbon sequestration services can easily be reduced by slash-and-burn agriculture. Furthermore, once carbon is sequestered, in principle, everyone on earth who cares about climate stability also immediately gets access to those benefits. Access to carbon sequestration as a form of ecosystem services is, therefore, open and potentially impossible to defend.

These common pool features of carbon sequestration services imply that it is difficult for businesses to earn profits (except perhaps as government or multilateral agency contractors) by providing them. Businesses, therefore, generally do not provide services like carbon sequestration (or for that matter, most other ecosystem services), which means that without government help there are no carbon markets, no carbon prices and potentially no carbon value.

The lack of carbon prices due to missing markets is believed to be particularly problematic. When prices are absent for something, some people may perceive the price as zero, which can be interpreted as meaning carbon sequestration services are not at all scarce and therefore a) there is no reason to provide them and b) we should use forests for other purposes ${ }^{1}$. This problem of not having market prices for many services is inherent in the management of all common pool resources. Such issues are

${ }^{1}$ This set of conclusions emerges from models of behaviour that presume that people primarily operate in their self-interest and are unwilling to sacrifice in meaningful ways for the greater good. This assumption certainly has limits. Indeed, without tendencies for cooperation, humans would probably long ago have completely degraded most ecosystems that have commercial value. Nevertheless, it is reasonable to suppose that self-interest plays a very important role in human behaviour. 
especially complicated in developing country forests because they provide a variety of sometimes conflicting common pool resource ecosystem services.

Developing appropriate REDD+ carbon markets is a potentially important tool to give value to forest ecosystem services. In the process, once valued properly, the hope is that REDD+ will create incentives for those who control forests to sequester carbon and for those who emit carbon into the atmosphere to pay for sequestration services. But what would cause such transactions to take place? Following the logic presented above, sequestering carbon must be in the interest of those who control forests and those who emit carbon. That is, both sides must benefit financially or in other key dimensions for REDD+ to work.

\section{THE IMPORTANCE OF OPPORTUNITY COSTS}

From the community managed forest perspective, the basic economics has everything to do with carbon prices and the opportunity costs of carbon sequestration (i.e. what communities and community members give up to sequester carbon). As long as carbon buyers offer benefits to communities that are more than communities' costs of providing carbon sequestration services, our basic behavioural model suggests that it will be in the interest of communities to sequester carbon. There must also be a match from the carbon buyer perspective. Carbon sequestration in nonAnnex 1 countries must, therefore, be perceived as relatively 'cheap' compared with other potential abatement options, such as fuel switching and installation of energy efficiency, among others.

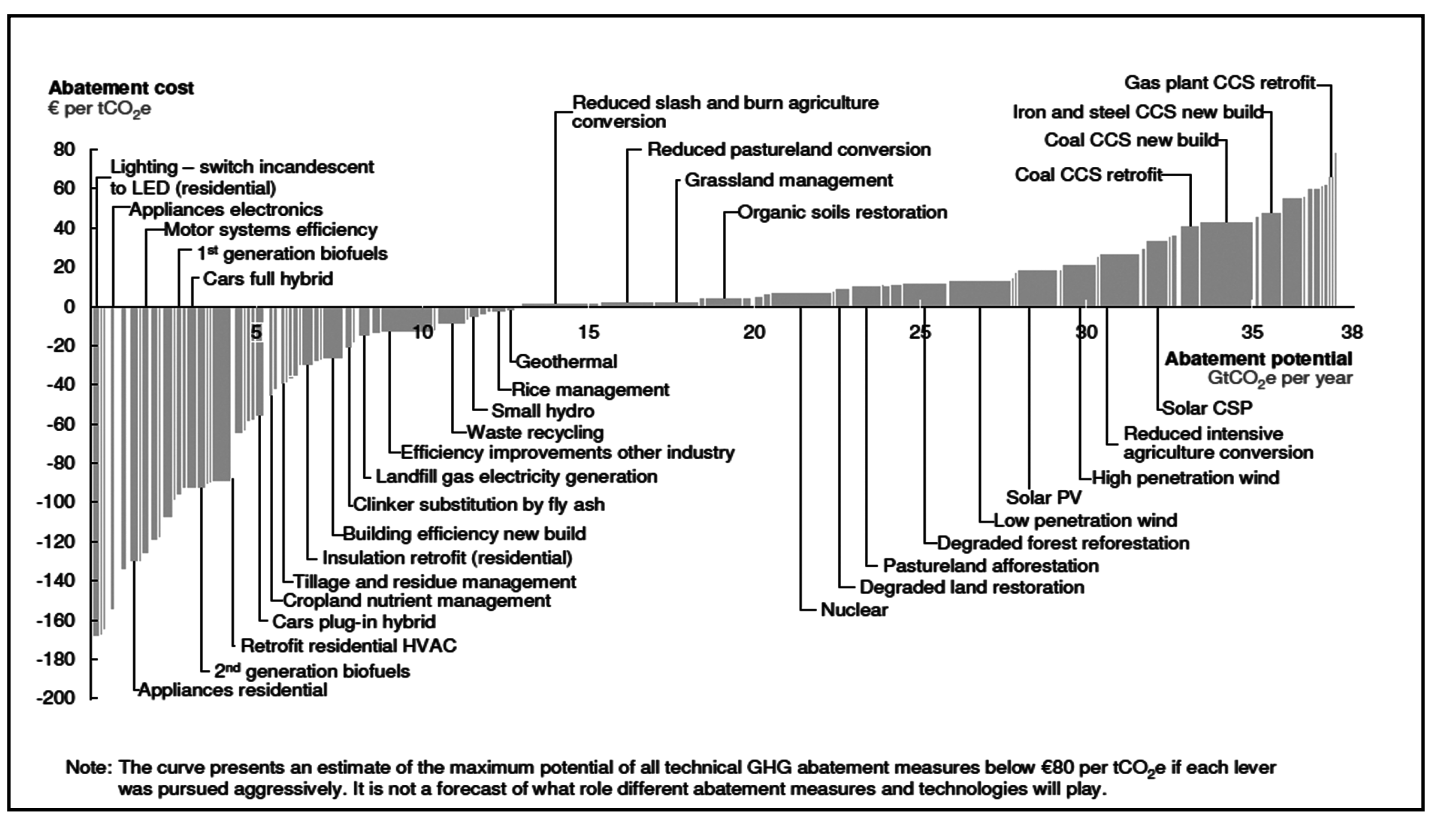

Figure 1: Costs to reduce carbon concentrations in the atmosphere

Source: McKinsey and Company (2010)

A particularly influential report was published by the consulting firm McKinsey and Company (2010). This paper ranked costs to reduce carbon concentrations in the atmosphere per ton of carbon reduced. One of the findings of the report, as summarized in Figure 1, is that 
carbon benefits from land improvements, such as degraded land restoration, reduced slash and burn agriculture and better forest management, could be achieved at a very low cost. For example, they estimate that reduced forest degradation, in addition to providing potentially significant co-benefits, could reduce carbon at less than $€ 10$ per ton. Similar results were also found using simulation techniques by Kindermann et al. (2008) and Strassburg et al. (2009), estimate that $80 \%$ of avoided deforestation costs less than US\$5.00 per ton of Carbon Dioxide $\left(\mathrm{CO}_{2}\right)$. Though controversy remains regarding whether all local opportunity costs of carbon sequestration were effectively included (Dyer and Counsel 2010; Gregorsen et al. 2011), such results suggest that forests may be able to effectively compete with other methods to reduce carbon in the atmosphere.

\section{POTENTIAL LINKS BETWEEN REDD+ AND COMMUNITY MANAGED FORESTS}

The findings of the above-stated studies generated a lot of interest because it is believed that deforestation and forest degradation are major sources of carbon emissions. Loss of forest biomass through deforestation and forest degradation accounts for 12-20 per cent of annual greenhouse gas emissions (Saatchi $e t$ al. 2011; van der Werf et al. 2009). UNEP (2012) estimates a smaller, though still significant, share at 11 per cent. In the 1990 s, it was estimated that deforestation, largely in the developing world, released about 5.8 gigatons of $\mathrm{CO}_{2}$ per year, which was more than all forms of transport combined. Total carbon stored in forests is estimated at 638 gigatons $\mathrm{CO}_{2}$ (UNFCCC 2011), with about 247 gigatons stored in Latin America, Sub-Saharan Africa and Southeast Asia. About 80 per cent of total sequestered carbon accounts to above ground (Saatchi et al. 2011).

Community managed forests could be a potentially important player because while most forests in developing countries are governmentowned in papers, in practice much of this forest is actually controlled, to an important degree, by the communities (Agrawal et al. 2008). About 25 per cent of developing country forests, or three times as much as is owned by the private sector, is under community ownership and/or administration and this percentage appears to be increasing over time. During the period 1997-2008, the area of collective ownership roughly doubled to 250 million hectares (World Bank 2009). Given the importance of community managed forests and the recent increases observed, it is difficult to envision a successful REDD+ without coming to terms with community managed forests.

And the use of forest biomass extracted from community managed forests also appears to be very important for climate change. Over two billion people around the world cook and heat with biomass on a regular basis, and most of this comes from community managed forests. Though fuelwood is in principle carbon neutral, the black carbon from biomass fuels for cooking and heating, particularly in Asia, is believed to be a key contributor to climate change. $\mathrm{CO}_{2}$ emissions cause about 40 per cent of anthropogenic climate change, but black carbon comes in second with perhaps as much as a 30 per cent contribution (Rosenthal 2009; Bond et al. 2013). Bond et al. (2013) find that 25 per cent of black carbon emissions come from residential cooking and heating, mostly in the developing world. Smith et al. (2000) find that, depending on the timeline examined, the global warming contribution of a meal cooked using biomass can be significantly higher than those for fossil fuels.

\section{KEY CAUTIONS IN MOVING AHEAD WITH REDD+}

The potential for REDD+ applied to community managed forests to contribute to climate change mitigation appears significant, but we must also ask what could be on the way 
of incentives for REDD+ transactions. An obvious point that applies not only to community managed forests or even to carbon sequestration is that at the present time, a very small percentage of firms in FCCC Annex 1 countries face binding limits on their carbon emissions. Except for voluntary motivations, including those related to altruism, public relations and hedging against future regulations, such firms have very limited incentives to purchase carbon sequestration credits. To make REDD+ markets work, economic actors that emit carbon in the developed world must, therefore, be subjected to binding caps.

Because Annex 1 country emitters typically do not have binding caps, private transactions are very limited. The crafters of REDD+, as discussed in Angelsen (2008), envisioned multiple types of REDD+ finance, with development assistance being one that is an 'order of magnitude' less than market finance (pp. 60, 110). In practice, as of 2013, REDD+ appears to be moving towards a fund-based institutional structure that some say is more like foreign aid than a true PES scheme. Such a trend has generated serious concerns about the 'aid-ification' of REDD+ (Evans 2012).

The second major reason why REDD may not work as hoped in community forest contexts is that costs may prove higher than expected and bargains cannot be reached. Costs associated with community negotiations, meetings, monitoring, risk aversion and high discount rates (Yesuf and Bluffstone 2009;2013) could turn out to be significant and potentially make communities unwilling to participate in REDD+ at prices carbon buyers would be willing to pay. This would, of course, imply that carbon sequestration from community managed forests would be too costly for Annex 1 buyers.

Particularly if hidden costs turn out to be very high, there may be risks that REDD+ could distort or destabilize well-functioning community managed forests. This very issue was examined by Elinor Ostrom and a variety of collaborators in the context of irrigation systems. As discussed in detail in Ostrom (1990), Ostrom and Gardner (1993) and Ostrom (2000; 2009), social systems supporting irrigation systems, like those related to community managed forests, are typically complicated, with very detailed rules and norms. These systems can be, and have been, destabilized by outside attempts to improve the efficiency of irrigation through, for example, construction of permanent headworks. Such steps have sometimes reduced incentives for reciprocity among farmers at the head and tail of irrigation systems, destabilizing social systems that were working reasonably well (Ostrom and Gardner 1993).

Third, while it is widely agreed that REDD+ should not impose excessive constraints on local processes or, much worse, forcibly take away existing community rights, these issues will remain as serious concerns. Bushley and Khatri (2011), Ostrom (2010) and Agrawal et al. (2011), all suggest that a core challenge is to create appropriate institutions for channelling REDD+ benefits and imposing costs on those who control community managed forests. All three authors note that critical inputs for getting institutions right are collaborative design processes between all levels of REDD+ actors (e.g. international, national and local), recognition of local rights and commitments to locally-tailored solutions.

A key overarching mechanism design issue, therefore, is how REDD+ benefits can effectively be transferred to the local level and additional costs apportioned without disrupting successful community management systems. Taking into account the seven design principles proposed in Ostrom (1990) and expanded in Ostrom (2009) and elsewhere, we know that group membership, benefit-sharing rules, fairness, public participation and social sanctioning are very important. Any REDD+

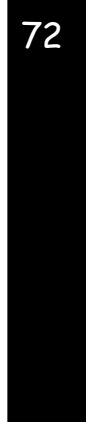


flows would likely raise the stakes associated with proper institutional design. If REDD+ is to go fo rward successfully, the structure of REDD+ funding mechanisms will, therefore, have to be closely linked with community management institutional structures.

There are a variety of issues particularly tied to the use of fund-based finance mechanisms (Bluffstone et al. 2013). First, such an approach probably cannot provide enough funding to meet developing country needs or to effectively exploit community managed forest carbon sequestration opportunities. Second, under such systems, governments hardly receive any REDD+ payments (Humphreys 2008) and will be monopsony ${ }^{2}$ buyers of carbon. Implicit in this approach is that government owns the carbon stock, gets the carbon rents and chooses to what extent and how to compensate villagers for lost access to forest resources. There is, therefore, a possibly legitimate concern that governments could set exploitative prices and terms. From their side, communities may view these terms as government requirements over which they have few bargaining rights.

There is also a tendency in the literature to think in terms of estimating opportunity costs and extracting carbon rents from local communities in order to purchase the most carbon possible with donor budgets (Gregorsen et al. 2011; Bakkegaard et al. 2012). Such approaches are not in harmony with free bargaining or community property rights and mechanisms should be developed that allow communities to earn rents as occurs in a variety of other circumstances. On the positive side, donors often are very supportive of approaches that involve local communities. A central role for donors may, therefore, protect communities when appropriate.

Very limited rigorous empirical research on REDD+ has been conducted within the context of community managed forests and I am aware of no economic analysis of compensation mechanisms and governance complexities associated with REDD+. To date, such issues have merely been raised by researchers and advocates as I am doing now. As I have tried to emphasize, the literature on social capital and community managed forests point to important cautions that should be respected and suggest a variety of practical details that must be addressed. These huge gaps in the economics literature must be at least partially closed before moving ahead with REDD+.

\section{REFERENCES}

Agrawal, A. Nepstad, D. and Chhatre, A. 2011. Reducing Emissions from Deforestation and Forest Degradation, Annual Review of Environment and Resources, 36: 373-396.

Agrawal, A. Chhatre, A. and Hardin, R. 2008. Changing Governance of the World's Forests. Science, 320: 1460-1462.

Angelsen, A. (Ed.). 2008. Moving Ahead with REDD: Issues, Options and Implications. CIFOR, Bogor, Indonesia.

Bakkegaard, R. K., Jacobsen, J. B. and Thorsen, B. J. 2012. Using a Hypothetical Auction Frame to Elicit Stated Compensation Needs to Avoid Deforestation among Households in the Brazilian Amazon," Paper Presented at the $19^{\text {th }}$ Annual Conference of the European Association of Environmental and Resource Economists, June 302012.

Bluffstone, R., Robinson, E. and Guthiga, P. 2013. REDD+ and Community Controlled Forests in Low-Income Countries: Any Hope for a Linkage? Ecological Economics, 87: 43-52.

Bond, T., Doherty, S., Fahey, D., Forster, P., Bernsten, T. DeAngelo, B., Flanner, M., Ghan, S., Karcher, B., Koch, D., Kinne, S., Kondo, Y., Quinn, P., Arofim, M., Schultz, M., Schulz, M., Venkataraman, C., Zhang, H., Zhang, S., Bellouin, N., Guttikunda, S., Hopke, P., Jacobsen, M., Kaiser, J., Klimont, Z., Lohmann, U., Schwarz, J., Shindell, D., Storelvmo, T., Warren, S. and Zender, C. 2013. Bounding the Role of Black Carbon in the Climate System: A Scientific Assessment. Journal of Geophysical Research Atmospheres, 118: 5380-5552. doi: 1002/jgrd.50171. Available at http://onlinelibrary.wiley. com/doi/10.1002/jgrd.50171/pdf

Bushley, B.R. and Khatri, D.B. 2011. REDD+: Reversing, Reinforcing or Reconfiguring Decentralized Forest

${ }^{2} \mathrm{~A}$ monopsonist is a single buyer in a market. 
Governance in Nepal? Discussion Paper 11: 3. Kathmandu: ForestAction Nepal.

Dyer, N. and Counsel, S. 2010. McREDD: How McKinsey 'Cost Curves' are Distorting REDD,' Rainforest Foundation UK Climate and Forests Policy Brief. November 2010.

Evans, K. 2012. The Aid-ification of REDD+: How It Changed and Why it Matters, Forest news: A blog by the Center for International Forestry Research. (http://blog.cifor.org/ 9583/the-aid-ification-of-redd-how-its-changed-and-whyit-matters/\#.UGnuxpjA_QQ accessed on 25 July 2013.)

Gregorsen, H. Lakany, H., Karsenty, A. and White, A. 2011. Does the Opportunity Cost Approach Indicate the Real Cost of REDD+? Rights and Realities of Paying for REDD+ at Washington, D.C.: Rights and Resources Initiative.

Humphreys, D. 2008. The Politics of 'Avoided Deforestation': Historical Context and Contemporary Issues. The International Forestry Review, 10(3): 429-442.

Kindermann, G. Obersteiner, M., Sohngen, B., Sathaye, J., Andrasko, K., Rametsteiner, E., Schlamadinger, B. Wunder, S. and Beach, R. 2008. Global Cost Estimates of Reducing Carbon Emissions through Avoided Deforestation. Proceedings of the National Academy of Science, 105: 1030210307

McKinsey and Company. 2010. Impact of the Financial Crisis on Carbon Economics: Version 2.1 of the Global Greenhouse Gas Abatement Cost Curve. (http://www.mckinsey.com/ clientservice/sustainability/pdf/ Impact Financial_Crisis_Carbon_Economics_GHGcostcurveV2.1.pdf accessed on 8 January 2011).

Ostrom, E. 1990. Governing the Commons: The Evolution of Institutions for Collective Action. New York: Cambridge University Press.

Ostrom, E. 2000. Collective Action and the Evolution of Social Norms. The Journal of Economic Perspectives, 14(3): 137-158.

Ostrom, E. 2009 . Beyond Markets and States: Polycentric Governance of Complex Economic Systems. Nobel Prize in Economic Sciences Lecture, December 8, 2009.

Ostrom, E. 2010. Keynote Address to the Tenth Annual Meeting of the South Asian Network of Development and Environmental Economists, 12/6/2010, Godavari, Nepal.
Ostrom, E. and Gardner, R. 1993. Coping with Asymmetries in the Commons: Self-Governing Irrigation Systems Can Work. The Journal of Economic Perspectives, 7(4): 93-112.

Rosenthal, E. 2009. Soot from Third-World Stoves is New Target in Climate Fight. The New York Times, 16 April, Vol. 54,647.

Saatchi, S. Harris, M., Brown, S., Lefsky, M., Mitchard, E., Salas, W., Zutta, B., Buermann, W., Lewis, S., Hagen, S., Petrova, S., White, L., Silman, M. and Morel, A. 2011. Benchmark Map of Carbon Forest Carbon Stocks in Tropical Regions across Three Continents. Proceedings of the National Academy of Sciences, 108(24): 9899-9904.

Smith, K. R., Uma, R., Kishore, V.V.N., Zhang, J., Joshi, V. and Khalil, M.A.K. 2000 Greenhouse Implications of Household Stoves: An Analysis for India. Annual Review of Energy and the Environment, 25: 741-63

Strassburg, B., Turner, R.K., Fisher, B., Schaeffer, R. and Lovett, A. 2009. Reducing Emissions from Deforestation The "Combined Incentives" Mechanism and Empirical Simulations. Global Environmental Change, 19: 265-278.

UNEP. 2012. “The Emissions Gap Report 2012: A United Nations Environment Program Synthesis Report (http:// www.unep.org/pdf/2012gapreport.pdf accessed on 25 July 2013)

UNFCCC. 2011. Fact Sheet: Reducing Emissions from Deforestation in Developing Countries. United Nations Framework Convention on Climate Change. Available at (http://unfccc.int/files/press/backgrounders/application/ pdf/fact sheet reducing emissions from deforestation.pdf accessed on 25 July 2013)

van der Werf, G.R., Morton, D.C., DeFries, R.S., Olivier, J.G.J., Kasibhatla, P.S., Jackson, R.B., Collatz, G.J. and Randerson, J.T. 2009. CO2 Emissions from Forest Loss. Nature Geoscience, 2: 737 - 738.

World Bank. 2009. Forests Sourcebook: Practical Guidance for Sustaining Forests in International Cooperation. Washington D.C.: The World Bank

Yesuf, M. and Bluffstone, R. 2009. Poverty, Risk Aversion and Path Dependence in Low Income Countries: Experimental Evidence from Ethiopia. American Journal of Agricultural Economics, 91(4): 1022-1037

Yesuf, M. and Bluffstone, R. 2013. Time Preference, Risk Aversion and Market Failures in Low Income Countries: Experimental Evidence from Rural Ethiopia. Under Review. 